\title{
The Free Movement of Goods in MERCOSUR: Developing a European Court of Justice Approach in MERCOSUR?
}

\author{
Yovana Reyes Tagle
}

\section{Recognition of the principle of free movement of goods in MERCOSUR law}

\subsection{Defining the principle of free movement of goods: the legal framework}

The Treaty of Asuncion ${ }^{2}$ signed in 1991 envisaged the creation of the Common Market of the South (MERCOSUR) by 31 December 1994. Article 1 of the Treaty of Asuncion establishes the free movement of goods as one of the components of the common market. This provision calls for the elimination of non-tariff restrictions and any other equivalent measure. Article 5 thereof provides for a transition period ending on 31 December 1994. During this period, the Trade Liberalization Program was envisaged as one of the main instruments for the conformation of the common market. This Program included the elimination of non-tariff restrictions or measures of equivalent effect as well as other restrictions on trade among State Parties.

Annex I of the Treaty of Asuncion regulates the Trade Liberalization Program. Article 1 of Annex I reiterates that State Parties shall eliminate restrictions on their reciprocal trade. Article 2 thereof defines the concept of restrictions, considering that this concept includes any administrative, financial, foreign exchange measure or measures of any kind, whereby a State Party through a unilateral decision, obstructs or hinders imports.

The Treaty of Asuncion employs a formula including general notions termed "measures of equivalent effect", "any other equivalent measure" and "measures of any kind". These concepts of restrictions are broader in scope. While Annex I of the Treaty of Asuncion seeks to clarify the notion of restrictions on trade, the catch-all notion of measures of equivalent effect remains undefined. State Parties have expressed the difficulties of interpreting the concept "equivalent nature or effect". Controversies over restrictive national measures have been brought before the arbitral tribunals and the Permanent Tribunal of Review (PTR). However, there have not been many cases which challenge the arbitral tribunals or the PTR to interpret

\footnotetext{
1 The author thanks the visiting fellowship from the "SECO/WTI Academic Cooperation Programme" which has made this paper possible.

2 The Treaty Establishing a Common Market between the Argentine Republic, the Federal Republic of Brazil, the Republic of Paraguay and the Eastern Republic of Uruguay signed on 26 March 1991 (hereinafter the Treaty of Asuncion).

${ }^{3}$ MERCOSUR/CCM/CT N $\mathrm{N}^{\circ}$ 8/ACTA No 01/99. XXI Reunión del Comité Técnico No 8: Restricciones y Medidas No Arancelarias, p.5.
} 
the concept of measures of equivalent effect. As yet, most of the cases have concerned the classic restrictions on trade such as prohibitions and licenses. ${ }^{4}$

The principle of free movement of goods is taken up again in the 1991 Protocol ACE No. 18 signed within the framework of the Treaty of Asuncion and as part of the Treaty. ${ }^{5}$ This Protocol reiterates the conceptualization of the Treaty of Asuncion concerning the free movement of goods, including the same definition of restrictions. In line with Article 10 of the Treaty of Asuncion, Article 11 of the 1991 Protocol ACE No. 18 emphasizes that by 31 December 1994, all non-tariff restrictions should have been eliminated. In addition, MERCOSUR secondary law has remarked the importance of the principle of free movement of goods as a basic aspect of the common market stipulated in the Treaty of Asuncion. ${ }^{6}$

Some exceptions to the general rule of elimination of restrictions have been provided for. According to Article 2 Annex I of the Treaty of Asuncion, the concept of restrictions does not cover measures taken in the situations spelled out in Article 50 of the 1980 Treaty of Montevideo. ${ }^{7}$ Article 50 states that:

"No provision under the present Treaty shall be interpreted as precluding the adoption and observance of measures regarding:

a. Protection of public morality;

b. Implementation of security laws and regulations;

c. Regulation of imports and exports of arms, munitions, and other war materials and, under exceptional circumstances, all other military equipment;

d. Protection of human, animal and plant life and health;

e. Imports and exports of gold and silver in bullion form;

f. Protection of national treasures of artistic, historical or archeological value; and

g. Exportation, use and consumption of nuclear materials, radioactive products or any other material used for the development and exploitation of nuclear energy."

This list of exceptions has some similarities to Article 36 Treaty on the Functioning of the European Union (TFEU). ${ }^{9}$ However, there are two distinctions that can be

\footnotetext{
4 Arbitral award issued on 28 April 1999 in Montevideo. Application by Brazil of Restrictive Measures to Reciprocal Trade with Argentina.

5 Acuerdo de Alcance Parcial de Complementación Económica suscrito entre Argentina, Brasil, Paraguay y Uruguay (Acuerdo $\mathrm{N}^{\circ}$ 18) [Economic Complementation Agreement $\mathrm{N}^{\circ} 18$ between Argentina, Brazil, Paraguay and Uruguay, hereinafter, the 1991 Protocol ACE No. 18]. Protocol signed on 29 November 1991.

${ }^{6}$ MERCOSUR/CMC/DEC. $\mathrm{N}^{\circ} 22 / 00$.

7 The Treaty Establishing the Latin American Integration Association (ALADI) was signed on 12 August 1980 (hereinafter the Treaty of Montevideo).

${ }^{8}$ An English version of the Treaty of Montevideo is available at:

http://www.sice.oas.org/trade/montev_tr/Montevle.asp\#chapVII (25.07.2013).
} 
observed between the two provisions. First, Article 36 TFEU sets out two specific conditions with which states have to comply. Their national measures must not constitute an arbitrary discrimination or a disguised restriction on trade. Neither Article 2 Annex I of the Treaty of Asuncion nor Article 50 Treaty of Montevideo incorporates these tests. In this way, these treaties leave the interpretation of the exceptions to the free movement of goods to secondary law or the dispute settlement organs. This interpretation will be the subject of our discussion below. Due to the lack of any qualification in the Treaty of Asuncion and the Treaty of Montevideo, the PTR had to give a response in the first case it had to deal with concerning how these provisions should be interpreted. Second, these Latin American treaties themselves do not allow derogation to the free movement of goods based on the protection of industrial and commercial property.

\subsection{Standstill clause}

Another aspect that needs to be addressed is that the Treaty of Asuncion does not explicitly declare a standstill clause. Different positions have been adopted by MERCOSUR members in respect of the existence of this clause in secondary law. In Argentina v. Brazil, Argentina argued that Mercosur Decisions of the Common Market Council CMC No. 3/94 and 17/97 enshrined a standstill obligation regarding non-tariff restrictions. Therefore, it argued that the reinsertion or reintroduction, and the insertion of new restrictions, is a breach of this obligation. ${ }^{10}$ However, Brazil took a different view and questioned the existence of such a clause. Brazil stated that Article 4 of the Mercosur Decision 3/94 refers instead to a national treatment and most favorable nation obligation for imports within Mercosur. ${ }^{11}$

The ad hoc arbitral tribunal in Argentina v. Brazil concluded that the undertaking to eliminate non-tariff restrictions encompasses those restrictions which were in force at the time of, and after, the entry into force of the Treaty of Asuncion. Hence, this obligation includes new restrictions as well as previous restrictions that have been reinserted. After observing the importance of the Tariff Reduction Program, the arbitral tribunal took the view that it is not possible to reintroduce non-tariff restrictions which have been eliminated or to impose new restrictions. Consequently, the arbitral tribunal correctly accepted the existence of a standstill clause in Mercosur. $^{12}$

\footnotetext{
${ }^{9}$ Article 36 TFEU provides for the list of exceptions to the general rule of Article 34 . This provision states that "The provisions of Articles 34 and 35 shall not preclude prohibitions or restrictions on imports, exports or goods in transit justified on grounds of public morality, public policy or public security; the protection of health and life of humans, animals or plants; the protection of national treasures possessing artistic, historic or archaeological value; or the protection of industrial and commercial property. Such prohibitions or restrictions shall not, however, constitute a means of arbitrary discrimination or a disguised restriction on trade between Member States."

${ }_{10}^{10}$ Arbitral award issued on 28 April 1999 in Montevideo. Case SECEX: Application by Brazil of Restrictive Measures to Reciprocal Trade with Argentina, para.18 [hereinafter Case SECEX).

${ }^{11}$ Case SECEX, para.39.

${ }^{12}$ Case SECEX.
} 


\section{The ad hoc arbitral tribunals' interpretation of the principle of the free movement of goods}

\subsection{The ad hoc arbitral tribunals' understanding of the role and importance of the principle of free movement of goods in MERCOSUR}

The arbitral tribunals have stressed the central role played by the Tariff Reduction Program in the integration process in MERCOSUR. ${ }^{13}$ The Treaty of Asuncion envisioned the establishment of a common market which should cease to be hampered by restrictions on trade of any kind no later than 31 December 1994. There have been changes concerning the initial date and objectives of conformation of a common market. MERCOSUR members decided to establish a customs union by 31 December 1999 as a step in the implementation of the common market. Despite these changes, the arbitral tribunals correctly argued that the obligations of the states to eliminate tariff and non-tariff restrictions have not been ruled out. ${ }^{14}$ The arbitral tribunals have noted that the Treaty of Asuncion does not provide for a procedure for the elimination of non-tariff barriers but it is not for the states to decide whether this elimination will take place or not in so far as the Treaty of Asuncion imposes on states a specific obligation. ${ }^{15}$ As a result, the arbitral tribunals have emphasized that from 31 December 1999, the principle of free movement of goods has been enshrined in MERCOSUR and any limitation or prohibition to this principle is prohibited. ${ }^{16}$

The arbitral tribunals agree that unless there is explicit provision to the contrary, the principle of free trade prevails in MERCOSUR. ${ }^{17}$ There is a clear position in defense of the free movement of goods in the case law of the arbitral tribunals in MERCOSUR. This was also confirmed when the arbitral tribunal in Brazil $v$. Argentina held that in a customs union like MERCOSUR there is a presumption in favor of free trade among its members. ${ }^{18}$ The absolute character of the prohibition of restrictions or measures having equivalent effect has been affirmed by an arbitral tribunal in the sense that such restrictions cannot be used by states even if the measure is not aimed at discriminating against foreign products. ${ }^{19}$ In light of this

13 Case SECEX, para.65-66 and 85 (v). See also Arbitral award issued on 21 May 2001 in Montevideo. Application of Anti-dumping Measures by Argentina against the Export of Chicken in Whole by Brazil, para.139-140.

${ }^{14}$ Case SECEX, para.72. See also Arbitral award issued on 21 May 2001 in Montevideo. Application of Anti-dumping Measures by Argentina against the Export of Chicken in Whole by Brazil, para.134.

15 Arbitral award issued on 28 April 1999 in Montevideo. Application by Brazil of Restrictive Measures to Reciprocal Trade with Argentina, para.68.

${ }^{16}$ Arbitral award issued on 21 May 2001 in Montevideo. Application of Anti-dumping Measures by Argentina against the Export of Chicken in Whole by Brazil, para.134-135.

17 Arbitral award issued on 10 March 2000, in Colonia, Uruguay. Application by Argentina of Safeguard Measures on Textiles from Brazil. p.84. See also Arbitral award issued on 21 May 2001 in Montevideo. Application of Anti-dumping Measures by Argentina against the Export of Chicken in Whole by Brazil, para.136.

18 Arbitral award issued on 10 March 2000, in Colonia, Uruguay. Application by Argentina of Safeguard Measures on Textiles from Brazil. p.84.

19 Arbitral award issued on 9 January 2002 in Montevideo. Prohibition by Brazil on the Import of Remolded Tires from Uruguay. p.180. 
decision, the discriminatory nature of a restrictive measure is not a requirement that must be met for it to fall within the concept of restriction or measures having equivalent effect.

The understanding of the scope of the principle of free movement of goods is broad enough to embrace not only non-tariff restrictions and measures of equivalent effect but also other restrictions on trade. All these measures had to be eliminated by 31 December 1999. ${ }^{20}$

In addition, the arbitral tribunals have defended the fulfillment of the liberalization of trade in MERCOSUR. The arbitral tribunals have used a teleological reading ${ }^{21}$ of the Treaty of Asuncion provisions. ${ }^{22}$ In this context, the importance of the interpretation of MERCOSUR law in connection with the liberalization of trade implemented by the Treaty of Asuncion has been addressed by the ad hoc arbitral tribunals in a number of cases. In Brazil v. Argentina, the arbitral tribunal emphasized that the MERCOSUR system aims at eliminating barriers to trade among its members and argued that every interpretation of the tribunal needs to be consistent with these purposes, which represent the object and ends of the agreement between members. The arbitral tribunal held that every interpretation should promote rather than inhibit those purposes. The arbitral tribunal relied on previous awards issued by arbitral tribunals which defended the importance of taking into account the purposes and objectives of a regional integration agreement when interpreting MERCOSUR rules. ${ }^{23}$ In the same vein, in another case between Brazil $v$. Argentina, the need to eliminate all barriers to trade as a central pillar of MERCOSUR led the arbitral tribunal to hold that any limitation to the free movement of goods should be analyzed on the basis of such an approach adopted by the Treaty of Asuncion and secondary law. ${ }^{24}$ The position adopted by the arbitral tribunal shows the understanding of the importance of the liberalization of trade for the interpretation of MERCOSUR law.

\footnotetext{
${ }^{20}$ Arbitral award issued on 28 April 1999 in Montevideo. Case SECEX: Application by Brazil of Restrictive Measures to Reciprocal Trade with Argentina, para.85 (vii).

${ }^{21}$ It should be noted that the ECJ has also used a teleological method of interpretation. As regards this method of interpretation, Fennelly notes that "The preferred language of the Court remains close to the van Gend en Loos formulation, namely that it is necessary to consider 'the spirit, the general scheme and the wording,' supplemented later by consideration of 'the system and objectives of the Treaty.' [footnote omitted] In more recent years, the idea of 'context' has been added, [footnote omitted] and the prevailing wording, varying minimally from case to case, has been that it is necessary when interpreting a provision of Community law to consider 'not only its wording, but also the context in which it occurs and the objects of the rules of which it is a part.' [footnote omitted]." Fennelly, Nial. Legal Interpretation at the European Court of Justice. Fordham International Law Journal, Vol. 20, Issue 3 1996, p.664.

${ }^{22}$ Arbitral award issued on 29 September 2001, in Asuncion, Paraguay. Restrictions on Access to the Argentina Market of Bicycles imported from Argentina.

23 Arbitral award issued on 10 March 2000, in Colonia, Uruguay. Application by Argentina of Safeguard Measures on Textiles from Brazil, p.71.

${ }^{24}$ Arbitral award issued on 21 May 2001 in Montevideo. Application of Anti-dumping Measures by Argentina against the Export of Chicken in Whole by Brazil, para. 140.
} 


\subsection{The Ad hoc Arbitral Tribunals' interpretation of the exceptions to the free movement of goods}

We reviewed the ad hoc arbitral tribunals' awards issued before and after the establishment of the PTR to identify the criteria or principles announced in these awards concerning the interpretation or application of the exceptions to the free movement of goods. This review shows that since the first arbitral award issued by an ad hoc arbitral tribunal in MERCOSUR, although there are no uniform criteria on how such exceptions should be applied, they have shown their concern for their proper application.

In MERCOSUR, an arbitral tribunal took the view that the obligation to eliminate non-tariff measures does not encompass the measures adopted within the scope of Article 50 of the Treaty of Montevideo. They have asserted that those measures should be aimed at achieving the ends specified by Article 50 of the Treaty of Montevideo and should not constitute commercial obstacles. ${ }^{25}$ In Argentina $v$. Brazil, the first ad hoc arbitral tribunal spelled out some conditions for the application of the exceptions to the free movement of goods in order to be compatible with Mercosur law. The arbitral tribunal expressed the view that the measure should be effectively aimed at protecting the objectives specified by Article 50 of the Treaty of Montevideo. Furthermore, the arbitral tribunal concluded with a reference to the European Court of Justice (ECJ) jurisprudence which affirmed the rejection of the establishment of formalities or conditions on imports, whatever their form, which constitute a distortion of trade, or measures which affect imported products more than national products, in law or in fact, as well as those measures which are not proportional to the end pursued. In addition, the arbitral tribunal concluded that measures adopted under the scope of Article 50 of the Treaty of Montevideo should be harmonized. ${ }^{26}$ Thus, the principle of proportionality of the measures adopted under the framework of Article 50 of the Treaty of Montevideo was announced by this tribunal, resorting to the ECJ jurisprudence. In the Remolded Tires case, Uruguay invoked these criteria announced by the arbitral tribunal as conditions for applying exceptions to the free movement of goods. However, the PTR shows its dissatisfaction with the proposal of Uruguay. ${ }^{27}$

A subsequent ad hoc arbitral tribunal has followed the approach taken by the arbitral tribunal in Argentina v. Brazil. In Brazil v. Argentina, the arbitral tribunal stated that the exceptions laid down in Article 50 of the Treaty of Montevideo should be effectively aimed at their own stated purposes in order to avoid a disguised restriction on trade. ${ }^{28}$ The case concerned the application of antidumping measures for poultry meat and therefore, the arbitral tribunal did not elaborate more on the scope of Article 50 of the Treaty of Montevideo. In this case, the arbitral tribunal

\footnotetext{
${ }^{25}$ Case SECEX, para. 81 and 85 (viii).

${ }^{26}$ Case SECEX, para. 81 and 85 (viii).

27 Arbitral award issued on 20 December 2005 in Asuncion. Award No. 1/2005. Prohibition by Argentina on the Import of Remolded Tires from Uruguay, para. 13.

28 Arbitral award issued on 21 May 2001 in Montevideo. Application of Anti-dumping Measures by Argentina against the Export of Chicken in Whole by Brazil, para.141.
} 
introduced the notion of a disguised restriction on trade which Article 50 does not incorporate. This concept is incorporated in Article XX of the General Agreement on Tariffs and Trade (GATT).

In Uruguay v. Brazil, the arbitral tribunal faced the question of the legality of the prohibition by Brazil on the import of remolded tires from Uruguay. The arbitral tribunal remarked that an important aspect for the states is the compatibility between free trade and domestic norms on the commercialization of products. The arbitral tribunal considered certain general principles which are relevant in the functioning of the integration process. First, the arbitral tribunal called upon states to consider that the reasons invoked by national authorities are subject to the principle of proportionality, namely barriers to trade are not to be accepted for the protection of goods where this could be achieved by less restrictive means. The arbitral tribunal put forward an example of these kinds of means: the information given to the consumer on the specifications and qualities of the goods purchased. ${ }^{29}$ Second, the arbitral tribunal relied on the existence of a sovereign reservation as one aspect of the integration process which allows members the possibility to impose barriers by unilateral decision and held that Article 50 of the Treaty of Montevideo, as an example of this sovereign reservation, limits the grounds of reservation to those situations it provided for. This is understood as the principle of limitation of the sovereign reservation. Third, the arbitral tribunal announced the principle of reasonable application, namely, national actions adopted by states should not exceed what is needed to achieve the proposed objectives. On the basis of this principle, it added that national actions cannot be arbitrary and infringe the principle of free circulation. Fourth, the arbitral tribunal identified the principle of commercial predictability. Legal certainty, clarity and objectivity are regarded as indispensable conditions and general rules for the commercial activities of State Parties and they are also essential for the trust in the common market. ${ }^{30}$ The arbitral tribunal concluded that the prohibition introduced by Brazil was a new restriction on trade and therefore a breach of MERCOSUR law.

It is noteworthy that in this case Brazil did not invoke any grounds of justification provided for in Article 50 of the Treaty of Montevideo. This may explain why the arbitral tribunal did not embark upon an in-depth analysis of this provision. However, it showed its concern over the manner in which State Parties apply restrictions on trade and the limitations to states' power to act.

Despite the lack of conditions for applying the exceptions of Article 50 of the Treaty of Montevideo, these cases show the clear understanding of the arbitral tribunals that such exceptions cannot be used without limits. They set some basic standards for their application. The arbitral tribunals have not only seized the opportunities to emphasize the fundamental role played by the principle of free movement of goods in the integration process in MERCOSUR but have also observed the need to apply

\footnotetext{
${ }^{29}$ Arbitral award issued on 9 January 2002 in Montevideo. Prohibition by Brazil on the Import of Remolded Tires from Uruguay, p.181.

${ }^{30}$ Arbitral award issued on 9 January 2002 in Montevideo. Prohibition by Brazil on the Import of Remolded Tires from Uruguay, p.181.
} 
the exceptions to this principle in a reasonable manner. Importantly, they recognized that there are limits to the State Parties' discretion to resort to these exceptions, namely, the mere invocation of an exception is not enough to accept its application.

Furthermore, arbitral tribunals have remarked that the burden of proof in Article 50 Treaty of Montevideo is on the State that invokes one of the exceptions. Restrictions to the free movement of goods shall be exceptional, specific and of restrictive interpretation. $^{31}$

\section{The PTR interpretation of the Treaty of Asuncion and the influence of the ECJ case law}

\subsection{The Remolded Tires case}

The facts of the Remolded Tires case are as follows. Argentina passed Law No. 25.626 on 8 August 2002 prohibiting imports of remolded tires. Uruguay questioned this national measure considering that it infringed MERCOSUR law. Argentina relied on Article 50 of the Treaty of Montevideo to assert that under this provision, measures to protect the environment, human and animal life, and plants are allowed. In Argentina's view, the prohibition aimed at preventing the potential damage caused by the remolded tires. ${ }^{32}$ An arbitral tribunal was established to decide on the case. This arbitral tribunal issued its award confirming that Law No. 25.626 was compatible with the Treaty of Asuncion and its Annex I. Uruguay brought the case before the PTR against the award, which revoked it. In the Remolded Tires case, the PTR attempted to lay the foundations for the application of the exceptions to the free movement of goods. It stressed that none of the MERCOSUR tribunals have addressed the four criteria discussed by the PTR in its award of 2005, and which the PTR considered needed to be applied. ${ }^{33}$

The PTR clarified that the exceptions to the free movement of goods should be narrowly interpreted. The PTR noted that there was no legal framework establishing in a clear and concrete manner the criteria that needed to be analyzed to invoke the exceptions to the free movement of goods. ${ }^{34}$ The PTR placed considerable emphasis on the gap identified in the provisions of the Treaty of Montevideo and reiterated this aspect throughout its complementary award. It also criticized the arbitral tribunal for its failure to note this legal loophole and fulfill its institutional role. According to the PTR such a role consists of establishing a clear and concise jurisprudence on the criteria to be applied to the case. ${ }^{35}$ The PTR took the view that

\footnotetext{
${ }^{31}$ Arbitral award issued on 19 April 2002 in Asuncion, Paraguay. Barriers to Entrance of Argentina Phytosanitary Products into the Brazilian Market, para.9.4.

32 Arbitral award issued on 25 October 2005 in Montevideo. Prohibition by Argentina on the Import of Remolded Tires from Uruguay, para.27.

${ }^{33}$ Complementary award issued on 13 January 2006 in Asuncion, Paraguay. Prohibition by Argentina on the Import of Remolded Tires from Uruguay, para.XVI and para.XVIII.

${ }^{34}$ Arbitral award issued on 20 December 2005 in Asuncion . Award No. 1/2005. Prohibition by Argentina on the Import of Remolded Tires from Uruguay, para. 10. [hereinafter Award No. 1/2005].

${ }^{35}$ Award No. 1/2005, para. 10.
} 
it is the task of a tribunal to establish the conditions to apply the exceptions to the free movement of goods which was an aspect that the arbitral tribunal failed to clarify. ${ }^{36}$ The PTR also observed that none of the tribunals in MERCOSUR had addressed this subject matter as it deemed necessary. ${ }^{37}$ Later on, the PTR asserted that the Environmental Framework Agreement in MERCOSUR did not contain any provision regarding these criteria. ${ }^{38}$ In the PTR's view, neither the Preamble nor the text of the Treaty of Asuncion provide for a contribution in relation to this legal loophole. ${ }^{39}$ The PTR felt that it had to come up with a solution to this aspect that the drafters of the Treaty of Asuncion had omitted to address. As we will see below, the PTR assessed the case brought before it with the ECJ case law.

\subsubsection{The first criterion: determination of the restrictive nature of a national measure}

The PTR declared that the first step in the analysis is to assess if the national measure at hand is effectively restrictive of free trade. The PTR did not hesitate to affirm that a prohibition on imports is a restriction on trade. Nonetheless, the PTR added that considering that this was a leading case it was apposite to briefly quote the jurisprudence of the ECJ which, in the PTR's view, perfectly matched the case at hand. ${ }^{40}$ The PTR built on the ECJ ruling on Commission v. Austria (Case C-320/03) of November 2005 and reproduced the following paragraphs to back up its position: "Clearly, by prohibiting heavy vehicles of more than 7.5 tonnes carrying certain categories of goods from travelling along a road section of paramount importance, constituting one of the main routes of land communication between southern Germany and northern Italy, the contested regulation obstructs the free movement of goods and, in particular, their free transit." 41 The PTR added the following ECJ conclusion: "The contested regulation must therefore be regarded as constituting a measure having equivalent effect to quantitative restrictions, which in principle are incompatible with the Community law obligations under Articles 28 EC and 29 EC, unless that measure can be objectively justified." ${ }^{42}$

Why was it necessary to introduce the ECJ jurisprudence in a leading case in MERCOSUR? Was the PTR attempting to defend the application of the ECJ jurisprudence as a source for the interpretation of MERCOSUR law? The PTR did not explain its reasons for introducing this reference. Besides, it should be noted that, in this case, the ECJ recalled its landmark Dassonville formula to reach its conclusion. ${ }^{43}$ The PTR was, perhaps without noting it, implicitly endorsing this

\footnotetext{
${ }^{36}$ Award No. 1/2005, para. 11.

${ }^{37}$ Award 1/2006, para. XVIII.

${ }^{38}$ Complementary award issued on 13 January 2006 in Asuncion, Paraguay. Prohibition by Argentina on the Import of Remolded Tires from Uruguay, para.XII.

${ }^{39}$ Complementary award issued on 13 January 2006 in Asuncion, Paraguay. Prohibition by Argentina on the Import of Remolded Tires from Uruguay, para.XIII.

40 Arbitral award issued on 20 December 2005 in Asuncion. Award No. 1/2005. Prohibition by Argentina on the Import of Remolded Tires from Uruguay, para.14.

${ }^{41}$ Case C-320/03, Commission v. Austria [2005] ECR 9930 (para.66).

${ }^{42}$ Case C-320/03, Commission v. Austria [2005] ECR 9931 (para.69).

${ }^{43}$ Case C-320/03, Commission v. Austria [2005] ECR 9930 (para.67).
} 
formula. The fact that the ECJ case law quoted did not directly refer to a prohibition on imports like the case being dealt with by the PTR supports this proposition. By doing so, they opened up the possibility for including a variety of measures that could be considered as restrictions on trade. It should be noted that the ECJ has regarded prohibitions on imports as restrictions on trade. In $R v$. Henn and Darby, ${ }^{44}$ the ECJ held that prohibitions on imports were "the most extreme form of restriction" and consequently this prohibition constituted a measure within the concept of quantitative restrictions. Likewise, the ECJ ruled in Iannelli v. Veroni ${ }^{45}$ that the prohibition in Article 34 of the Treaty on the Functioning of the European Union (TFUE) is aimed at "those measures prohibiting imports in whole or in part". However, the PTR chose to quote a case that did not concern prohibitions on imports. In this context, it is not clear why the PTR claimed that the ECJ's jurisprudence perfectly matched the case in MERCOSUR. It is submitted that the utilization of the ECJ case law by the PTR to explain the first criterion was unnecessary.

Moreover, it can also be observed that the order of assessment employed to determine whether a national measure adopted by a State Party constitutes a restriction on trade sought to duplicate the manner in which the ECJ has assessed national measures in the EU. Gormley observes that the classical Dassonville approach of addressing alleged restrictions on trade consists of two steps: the analysis of whether "there is clearly a barrier to trade between Member States, and then proceeding to deal with the alleged justification." ${ }^{\text {" In }}$ the quotation of the ECJ ruling, the PTR highlighted the phrase "unless that measure can be objectively justified", suggesting that the same order of assessment followed by the ECJ will be followed by the PTR. Nonetheless, the PTR, after determining the existence of the restriction on trade, continued to analyze the discriminatory nature of the restriction at issue.

Surprisingly, the PTR did not elaborate further on the interpretation of the concept of restrictions on imports enshrined in Annex 1 of the Treaty of Asuncion, in particular in light of the PTR's willingness to set up jurisprudence.

\subsubsection{The second criterion: the discriminatory nature of the measure}

The PTR pointed out that after determining the existence of a restriction on trade, it is necessary to address the question of whether or not such a measure is discriminatory. Again, the PTR responded to the question with a reference to the ECJ jurisprudence and stated that any measure can be directly or indirectly discriminatory. There is indirect discrimination when the measure is applied to

\footnotetext{
${ }^{44}$ Case 34/79, R v. Henn and Darby [1979] ECR 3795.

${ }^{45}$ Case 74/76, Iannelli v. Veroni. [1977] ECR 557.

${ }^{46}$ Gormley, Laurence W. Free Movement of Goods and Their Use - What Is the Use of It? In: Fordham International Law Journal Vol. 33, Issue 6, 2011, p. 1597.
} 
nationals and foreigners alike, but its effects are greater on foreigners than nationals. $^{47}$

The PTR also looked to the Opinion of the Advocate General Geelhoed delivered on 14 July 2005 for guidance. This Opinion was issued on the occasion of the case Commission v. Austria (Case C-320/03) mentioned above. Notably, the PTR strictly followed the four questions addressed by the Advocate General Geelhoed concerning the compatibility of the national measure at hand with Articles 28 and 30 EC (Article 34 and 36 TFUE) in order to set out the four criteria for analyzing the exceptions to the free movement of goods in light of Article 50 of the Treaty of Montevideo.

The PTR quoted the position of the Advocate General when he held that "According to the Court's general approach to the possibility of justifying restrictions to intraCommunity trade, only measures which are indistinctly applicable to national goods and goods imported from other Member States can be justified on grounds of imperative requirements relating to the general interest, including the protection of the environment." 48 The PTR continued with the reference to the Opinion of the Advocate General: "It is settled case-law that discrimination can arise only through the application of different rules to comparable situations or the application of the same rule to different situations." prohibition adopted by Argentina was directly discriminatory because it affected only foreign products. ${ }^{50}$ Clearly, a prohibition on imports always affects only imported products.

The PTR held that the determination that the measure was of a discriminatory character does not render it unviable but rather it was just a second step in the analysis to be followed. In the PTR's view, this led to the obligation to analyze the third criterion. This approach of the PTR merits further consideration.

It should be noted that one of the approaches followed by the ECJ when assessing national rules in the light of Article 34 TFEU is that "it has (1) simply noted that the national measure 'impedes', 'hinders', or creates an 'obstacle' to inter-state trade, making little or no reference to the question of discrimination, and then (2) considered whether a mandatory requirement or an Article 36 derogation applies." In Commission v. Austria, Advocate General Geelhoed justified the analysis on the

\footnotetext{
47 Arbitral award issued on 20 December 2005 in Asuncion . Award No. 1/2005. Prohibition by Argentina on the Import of Remoulded Tyres from Uruguay, para. 15.

48 Commission v. Austria. Opinion of Advocate General Geelhoed delivered on 14 July 2005, para.89.

${ }^{49}$ Commission v. Austria. Opinion of Advocate General Geelhoed delivered on 14 July 2005, para.90.

50 Arbitral award issued on 20 December 2005 in Asuncion. Award No. 1/2005. Prohibition by Argentina on the Import of Remolded Tires from Uruguay, para. 15.

${ }^{51}$ Barnard, Catherine. The substantive law of the EU: The four freedoms. Oxford University Press: New York, 2010, p.103.
} 
determination of the discriminatory character of the measures being aware of the ECJ position concerning the grounds for justifications of the derogation of the principle of free movement of goods. Advocate General Geelhoed held:

"Next it must be determined whether or not the contested measure is discriminatory in character. This is important for determining which grounds can be invoked for justifying it. According to the Court's general approach to the possibility of justifying restrictions to intra-Community trade, only measures which are indistinctly applicable to national goods and goods imported from other Member States can be justified on grounds of imperative requirements relating to the general interest, including the protection of the environment. If the measure must be deemed to be indirectly discriminatory, it can only be justified on the grounds listed in Article 30 EC." 52 (Emphasis added)

The PTR was not distinguishing very clearly between the two-tier-approach to the exceptions laid down in Article 36 TFUE and the "imperative requirements" developed by the ECJ. The PTR failed to note that the analysis of discrimination proposed by Advocate General Geelhoed followed the ECJ approach concerning the exceptions to the principle of free movement of goods. The ECJ has accepted in its jurisprudence that there are treaty-based exceptions (Article 36 TFUE) as well as the "imperative requirements" developed in the Cassis de Dijon ruling in the light of EU law. ${ }^{53}$ These "imperative requirements" have been developed in the case law of the ECJ, and unlike the list contained in Article 36 TFUE; the imperative requirements are not an exhaustive list. These imperative requirements were determined by the ECJ as an additional exception to Article 36 TFUE. Moreover, as Weatherill put it "The Court $[\mathrm{ECJ}]$ remains resolute in refusing formally to abandon the rule that mandatory requirements cannot be invoked to justify discriminatory measures." 54 Consequently, the analysis of discrimination proposed by the PTR has been grounded in a different assessment scheme.

In the Remolded Tires case, Argentina invoked the exceptions explicitly set out by Article 50 of the Treaty of Montevideo and the protection of the environment. However, the PTR approached the question of the exceptions with the reference to "imperative requirements". Was the PTR attempting to accept and develop the "imperative requirements" as the ECJ did? It is not clear what the purpose of the declaration of the discriminatory character of a measure is in the application of exceptions to the free movement of goods. The PTR decided that the measure

\footnotetext{
52 Commission v. Austria. Opinion of Advocate General Geelhoed delivered on 14 July 2005, para.89.

${ }^{53}$ Case 120/78 Rewe-Zentral AG v Bundesmonopolverwaltung für Branntwein [1979] E.C.R. 00649. In the Cassis de Dijon ruling, the ECJ held that "obstacles to movement within the Community resulting from disparities between the national laws relating to the marketing of the products in question must be accepted in so far as those provisions may be recognised as being necessary in order to satisfy mandatory requirements relating in particular to the effectiveness of fiscal supervision, the protection of public health, the fairness of commercial transactions and the defence of the consumer", para.8.

${ }^{54}$ Weatherill, Stephen. Free Movement of Goods. The International and Comparative Law Quarterly, Vol. 52, No. 4 (Oct., 2003), p.1027.
} 
adopted by Argentina was discriminatory but it did not take up this aspect again in its analysis. Such a determination was not relevant for the determination of the acceptance, or not, of the restriction as an exception. Regardless of its discriminatory character, the measure was a restriction on trade.

Furthermore, the PTR concluded with a reference to the opinion of the ECJ ruling in De Peijper: "Health and the life of humans rank first among the property or interests protected by Article 36 and it is for the Member States, within the limits imposed by the Treaty, to decide what degree of protection they intend to assure and in particular how strict the checks to be carried out are to be." 55 The PTR also quoted the following statement of the ECJ: "National rules or practices do not fall within the exception specified in Article 36 if the health and life of humans can [be] as effectively protected by measures which do not restrict intra-Community trade so much." ${ }^{, 56}$ This quotation illustrates how the PTR refers to the ECJ case law to back up its own opinion.

\subsubsection{The third criterion: the justification of the measure}

The PTR focused on the object of the measure adopted by Argentina. Relying on the same ECJ ruling in Commission v. Austria, the PTR cited the writings of the ECJ:

"It is settled case-law that national measures capable of obstructing intraCommunity trade may be justified by overriding requirements relating to protection of the environment provided that the measures in question are proportionate to the aim pursued (see, in particular, Case C-463/01 Commission v Germany [2004] ECR I-11705, paragraph 75, and Case C309/02 Radberger Getränkegesellschaft and S. Spitz. [2004] ECR I-11763, paragraph 75).",57

The PTR has invoked in particular what the ECJ pointed out in its ruling: "In this case, it is undisputed that the contested regulation was adopted in order to ensure the quality of ambient air in the zone concerned and is therefore justified on environmental protection grounds." 58 The PTR after pointing out that the ECJ analyzed the form and the measures adopted by the national regulation, quoted the reasoning of the ECJ "....even if one were to concede that the contested regulation is based on Article 8(3) of Directive 92/62, it cannot be regarded as constituting a correct and full implementation of that provision." according to the understanding of the ECJ, quoted what the European court had held: "The above finding does not, however, preclude the possibility that the obstacle to the free movement of goods arising from the traffic ban laid down by the contested regulation might be justified by one of the imperative requirements in the public interest endorsed by the case-law of the Court of Justice."60 (Emphasis

\footnotetext{
${ }^{55}$ Case C-104/75 De Peijper [1976] ECR 635, para. 15.

${ }^{56}$ Case C-104/75 De Peijper [1976] ECR 636, para. 17.

${ }^{57}$ Case C-320/03, Commission v. Austria [2005] ECR 9931 (para. 70).

${ }^{58}$ Case C-320/03, Commission v. Austria [2005] ECR 9931 (para. 71).

${ }^{59}$ Case C-320/03, Commission v. Austria [2005] ECR 9934 (para. 83).

${ }^{60}$ Case C-320/03, Commission v. Austria [2005] ECR 9935 (para. 84).
} 
added) Again, the reference to the "imperative requirements" raises the question of whether the PTR was aware of the acceptance of non-treaty based exceptions in a leading case where it wanted to set up jurisprudence on Article 50 of the Treaty of Montevideo.

The PTR not only quoted the ECJ jurisprudence but also remarked that it was following and applying the stated jurisprudence to the facts of the case to assert that Argentina's measure could not be justified. The PTR noted that besides the protection of the environment, Argentina's prohibition aimed at protecting the national industry providing remolded tires. The PTR held that the analysis could be concluded with this finding. However, the PTR embarked upon the analysis of the fourth criterion making clear that this analysis should only be undertaken if the measure turns out to be justified.

\subsubsection{The fourth criterion: the principle of proportionality}

Similarly, the PTR's approach to proportionality is grounded in the case-law of the ECJ. The PTR regards the analysis of proportionality as the most difficult criterion to address taking into account that all measures that hinder free trade should be narrowly interpreted. First, the PTR stressed the conclusion of Advocate General Geelhoed in Commission v. Austria: "...the manner in which the contested measure was prepared and was intended to be introduced, infringes the principle of proportionality." ${ }^{\text {"61 }}$ Later, the PTR quoted the ECJ's reasoning: "In order to establish whether such a restriction is proportionate having regard to the legitimate aim pursued in this case, namely the protection of the environment, it needs to be determined whether it is necessary and appropriate in order to secure the authorised objective." 62 The PTR continued by quoting the ECJ ruling: "In the light of the above, it must be concluded that, because it infringes the principle of proportionality, the contested regulation cannot validly be justified by reasons concerning the protection of air quality. Therefore, that regulation is incompatible with Articles 28 EC and 29 EC." 63

The PTR noted that the concepts of justification and proportionality are interlinked. In order to understand the concept of proportionality, the PTR employed the Guide to the Concept and Practical Application of Articles 28-30 EC of 2001 ${ }^{64}$ (now Articles 34-36 of the TFEU) which, as the PTR argued, commented on the lessons to be learned from the ECJ Cassis de Dijon ruling. The PTR stressed that according to this Guide, "The three requirements of necessity, proportionality, and means which least hinders trade are to all to be regarded as expressions of the general principle of proportionality." 65

\footnotetext{
${ }^{61}$ Commission v. Austria. Opinion of Advocate General Geelhoed delivered on 14 July 2005, para. 116.

${ }^{62}$ Case C-320/03, Commission v. Austria [2005] ECR 9935 (para. 85).

${ }^{63}$ Case C-320/03, Commission v. Austria [2005] ECR 9936 (para. 91).

${ }^{64}$ Philipson, A. Guide to the Concept and Practical Application of Articles 28-30 EC. European Commission, Internal Market DG, 2001.

${ }^{65}$ Philipson, A. Op.cit. p.10.
} 
Citing the ECJ case law as an example, the PTR found the prohibition introduced by Argentina disproportionate. Among other reasons, the PTR asserted that trade could not be restricted unless it was the only available measure, and that the prohibition did not prevent damage. Instead, the measures adopted should be aimed at limiting and eliminating disused tires. ${ }^{66}$ Consequently, the PTR declared the non-compliance by Argentina of the provisions of MERCOSUR law based on what the PTR deemed was a correct interpretation and application of the exceptions laid down in Article 50 of the Treaty of Montevideo. The review of the four criteria applied by the PTR in the Remolded Tires case reveals that the jurisprudence of the ECJ has been decisive for the PTR award.

\subsection{Defending the application of the ECJ jurisprudence in MERCOSUR}

Argentina formally requested clarifications on its decision from the PTR. ${ }^{67}$ Nonetheless, it is clear that this was its way of questioning the PTR decision or asking the tribunal to provide additional justifications for its award. Indeed, Argentina expressed its disagreement with the utilization of foreign jurisprudence in this request. The PTR complementary award No. 1/2006 reflects a court attempting to find arguments to justify the use of the ECJ and the Andean Court of Justice jurisprudence.

Article 2 Annex I of the Treaty of Asuncion provides a framework for judicial review of State actions on market access. In the absence of treaty-based-conditions, the PTR feels that it is responsible for filling the gap left by the Treaty of Asuncion. ${ }^{68}$ The PTR has defended its own task to develop the concepts to understand MERCOSUR law and expressed its own view of its duty to interpret MERCOSUR law, recalling the role played by other tribunals in regional integration processes. In its award No. 1/2006, the PTR recalled that historically the tribunals in the integration processes developed the concepts that gave life to integration and community law. The PTR noted that the majority of the fundamental features of such a law were originally developed by the jurisprudence as a result of the work of their tribunals in response to their historical and institutional responsibility in an integration process. ${ }^{69}$ It can be inferred that the PTR was thinking of the ECJ when it made this statement and the PTR's willingness to play this role.

\footnotetext{
66 Arbitral award issued on 20 December 2005 in Asuncion, Paraguay. Award No. 1/2005. Prohibition by Argentina on the Import of Remolded Tires from Uruguay, para. 17.

${ }^{67}$ Pursuant to Article 28 of the Protocol of Olivos, any State party to the controversy can request clarification of the decision of the ad hoc arbitral tribunal or the PTR and on how such a decision is to be implemented.

${ }^{68}$ Complementary award issued on 13 January 2006 in Asuncion, Paraguay. Prohibition by Argentina on the Import of Remolded Tires from Uruguay, para. XII. Arbitral award issued on 20 December 2005 in Asuncion. Award No. 1/2005. Prohibition by Argentina on the Import of Remolded Tires from Uruguay, para. 10.

${ }^{69}$ Complementary award issued on 13 January 2006 in Asuncion, Paraguay. Prohibition by Argentina on the Import of Remolded Tires from Uruguay, para. XXIX. Arbitral award issued on 20 December 2005 in Asuncion. Award No. 1/2005. Prohibition by Argentina on the Import of Remolded Tires from Uruguay, para. 10.
} 
Despite the opposition of Argentina concerning the application of foreign sources as sources of law, the PTR responded that the careful and thoughtful utilization of foreign jurisprudence cannot be considered unacceptable as Argentina argued. ${ }^{70}$ What is to be understood by a careful and thoughtful utilization of foreign jurisprudence? The PTR did not shed further light on how and why its award grounded on the ECJ case law contained a careful and thoughtful utilization of foreign jurisprudence. For example, there is no reasoning in the PTR award as to the similarities of the concepts employed by the foundational treaties in MERCOSUR and the EU. There is no further reference to the differences in institutional architecture between MERCOSUR and the EU. There is no analysis concerning the different cases dealt with by the ECJ and the PTR. It is noteworthy that in MERCOSUR some countries, such as Uruguay and Argentina, have invoked the ECJ case law before arbitral tribunals within the framework of the MERCOSUR law. In response to the references made by State Parties, in Uruguay v. Argentina, the arbitral tribunal explained its reluctance to follow the ECJ case law and noted, among other aspects, the differences between the EU and MERCOSUR systems, the former being of a supranational nature. ${ }^{71}$ As will be discussed below, a critical assessment of the ECJ case law entails the consideration of such jurisprudence together with other data.

Besides, in response to Argentina's request for clarification of the PTR award, the PTR argued that there was no need to resort to any jurisprudence to hold that a prohibition on imports constitutes a restriction on free trade. However, the PTR justified its choice to quote the ECJ jurisprudence when determining the restrictive nature of a prohibition on imports. In the PTR's view, the quotation of the ECJ case law was done to provide a better illustration of the restrictive nature of such a measure. ${ }^{72}$ Was the PTR really providing a better illustration of the case by using the ECJ's opinion in Commission v Austria? The important point here is that there are treaties in MERCOSUR that had regarded prohibitions on imports as non-tariff restrictions. Then, why did the PTR need to illustrate the restrictive nature of such a measure with the ECJ jurisprudence? It seems that the PTR wanted to legitimatize the decision with a reference to the case law of a court that has a considerable reputation. Arguably, the PTR had other sources in MERCOSUR law to affirm that a prohibition on imports constituted a non-tariff restriction prohibited in the light of the Treaty of Asuncion. To begin with, non-tariff restrictions such as prohibitions on imports applied by State Parties were listed in the Notas Complementarias to the 1991 Protocol ACE No. $18 .^{73}$ Similarly, the Annex of the 1994 Additional Protocol

\footnotetext{
${ }^{70}$ Complementary award issued on 13 January 2006 in Asuncion, Paraguay. Prohibition by Argentina on the Import of Remolded Tires from Uruguay, para. XVIII.

71 Arbitral award Uruguay v. Argentina "Omisión del estado argentino en adoptar medidas apropiadas para prevenir y/o hacer cesar los impedimentos a la libre circulación derivados de los cortes en territorio argentino de vías de acceso a los puentes internacionales Gral. San Martín y Gral. Artigas que unen la República Argentina con la República Oriental del Uruguay”, para. 150.

${ }^{72}$ Complementary award issued on 13 January 2006 in Asuncion, Paraguay. Prohibition by Argentina on the Import of Remolded Tires from Uruguay, para. XIX.

${ }^{73}$ Notas Complementarias, the 1991 Protocol ACE No. 18. See the list of Argentina, Paraguay, and Uruguay.
} 
ACE No. 18 in MERCOSUR ${ }^{74}$ listed some non-tariff restrictions that State Parties had to eliminate and considered that prohibitions on imports were non-tariff restrictions. These Protocols represent the consensus among State Parties in MERCOSUR of what measures are to be regarded as non-tariff restrictions.

Additionally, MERCOSUR Decision of the Common Market Council (CMC) No. 3/94 registered a list of non-tariff restrictions which should be harmonized or eliminated. Prohibitions on imports were classified in the list as non-tariff restrictions. Furthermore, MERCOSUR Resolution of the Common Market Group (CMG) No. 123/94 expressed the need for elimination of non-tariff-restrictions listed in Decision No. 3/94 as a means to ensure market access for companies and productive sectors of State Parties. This Resolution also listed non-tariff restrictions which should be eliminated. Again, prohibitions on imports were included in the list as non-tariff restrictions. Therefore, MERCOSUR law clearly sets out the restrictive nature of prohibitions on imports. All these examples of legislation could serve as a legal background in the analysis of restrictions on imports in light of the Treaty of Asuncion. Surprisingly, the PTR omitted to make any reference to this legislative history in MERCOSUR that could have settled in a definitive manner that such a prohibition was an illegal restriction on trade. Instead, the PTR decided to quote the ECJ case law to affirm that a prohibition is a restriction.

We have discussed elsewhere that some Andean Community members have shown their reluctance to accept the application of the ECJ jurisprudence by their own community institutions in the definition of restrictions on trade. ${ }^{75}$ This kind of reluctance was also seen in MERCOSUR when the PTR had to respond to the clarification requested by Argentina on the question of application of foreign jurisprudence. Although the PTR correctly argued that the restrictive nature of a prohibition on imports is obvious, ${ }^{76}$ it is submitted that the tribunal could have paid closer attention to the internal sources before quoting the ECJ's jurisprudence to develop the concept of restriction on trade. There are sufficient grounds in MERCOSUR law, which turns out to be more illustrative than the ECJ jurisprudence in the determination of restrictions on trade, in particular in the case of the most common or classic restrictions such as import licenses, previous import authorizations, import controls, inspection certificates, etc. All of them have already been classified as non-tariff restrictions in MERCOSUR. ${ }^{77}$

Notably, as mentioned above, the ECJ ruling in Commission v Austria (C-320/03) quoted by the PTR did not directly concern a prohibition on imports, but rather a

\footnotetext{
${ }^{74}$ Acuerdo de Complementación Económica № 18 celebrado entre Argentina, Brasil, Paraguay y Uruguay (ACE No. 18), Additional Protocol signed on 30 December 1994.

${ }^{75}$ Reyes Tagle, Yovana. Free Movement of Goods in the Andean Community: How far can Dassonville go? SECO/WTI Academic Cooperation Project Working Paper Series 8/2012.

Available at: http://www.wti.org/fileadmin/user_upload/wti.org/7_SECOWTI_Project/Publications/Reyes\%20Tagle\%20FMG\%20dic\%202012.pdf.

${ }^{76}$ Complementary award issued on 13 January 2006 in Asuncion, Paraguay. Prohibition by Argentina on the Import of Remolded Tires from Uruguay, para. XIX.

${ }^{77}$ See for example CMC Decision 3/94.
} 
prohibition on transport which, because of the way in which it was applied, was considered as a measure of equivalent effect to quantitative restrictions. The ECJ held that by prohibiting lorries of more than 7.5 tonnes carrying certain goods, from driving on the section of the A12 motorway in the Inn Valley, Austria breached Article 28 EC (now Article 34 TFEU). After recalling its landmark Dassonville formula, the ECJ held that "it cannot be denied that the prohibition on traffic laid down by the contested regulation, by forcing the undertakings concerned at very short notice moreover, to seek viable alternative solutions for the transport of goods covered by that regulation, is capable of limiting trading opportunities between northern Europe and the north of Italy." 78 Therefore, how the PTR expected to illustrate the situation better through reference to this case is not clear.

On the other hand, in 2007, the idea of MERCOSUR secondary law as a reference point in the definition of restrictions on trade within the scope of Article 2 b) Annex I of the Treaty of Asuncion was envisaged. Article 1 of the MERCOSUR Decision of the Common Market Council No. 27/2007 provides that States Parties had to send to the Pro Tempore Presidency, before the last meeting of the Common Market Group in 2007, lists including the more relevant non- tariff restrictions and measures which made it difficult for them to export to the territories of the other State Parties. This provision states that the non-tariff restrictions and measures will be defined according to Article $2 \mathrm{~b}$ ) Annex I of the Treaty of Asuncion. Notably, this provision adds that for the purpose of such a definition, Decision No. 3/94 and all other MERCOSUR laws on this subject matter are valid as a precedent. Thus, arbitral tribunals, when deciding a case on the breach of the principle of free movement of goods, could also use all the decisions, resolutions and directives issued in MERCOSUR that classify national measures as non-tariff restrictions for an illustration.

A review of the awards of these arbitral tribunals reveals that such awards have been taken into account and quoted as background information or precedent to support the reasoning of subsequent arbitral awards. Concepts such as teleological interpretation are present in several arbitral tribunals' awards. ${ }^{79}$ As Vinuesa notes, such a reference to previous precedents is intended "to reinforce the idea of recognizing common patterns in the application and interpretation of Mercosur law." 80 Yet, the ad hoc arbitral tribunals in MERCOSUR have shown their willingness to keep some coherence and uniformity as regards the concepts and ways of interpreting MERCOSUR law.

\footnotetext{
78 Arbitral award issued on 20 December 2005 in Asuncion, Paraguay. Award No. 1/2005. Prohibition by Argentina on the Import of Remolded Tires from Uruguay, para. 68.

${ }^{79}$ Case SECEX para. 57-61, 85 (iii). See also Arbitral award issued on 27 September 1999, in Asuncion, Paraguay. Laudo del tribunal arbitral ad hoc del MERCOSUR constituido para entender en la reclamación de la republica argentina al Brasil, sobre subsidios a la producción y exportación de carne de cerdo, para. 55. Arbitral award issued on 21 May 2001 in Montevideo. Application of Antidumping Measures by Argentina against the Export of Chicken in Whole by Brazil, para. 17. Arbitral award issued on 29 September 2001, in Asuncion, Paraguay. Restrictions on Access to the Argentina Market of Bicycles imported from Argentina. Section 3.1.

${ }^{80}$ Vinuesa, Raúl Emilio. Enforcement of Mercosur Arbitration Awards Within the Domestic Legal Orders of Member States. In Texas International Law Journal Vol. 40 (2005), p. 433.
} 
The PTR approached the exceptions to the principle of free movement of goods from a different perspective, stating that it is not bound by any precedent of any MERCOSUR tribunal, let alone the decisions of an ad hoc arbitral tribunal. ${ }^{81}$ While it is true that the PTR is not bound by the principles laid down in decisions delivered by the ad hoc arbitral tribunals (actually, it is not even bound by its own jurisprudence), paradoxically, the manner in which the PTR followed the ECJ case law in its first case suggests that the PTR is binding itself to the jurisprudence of the ECJ. As mentioned above, the PTR held that since the Remolded Tires case was a leading case, it was required to cite the ECJ case law suggesting that it will follow such case law in subsequent cases.

Having carried out a review of the case law of the ad hoc arbitral tribunals, it is fair to say that the arbitral tribunals had already announced some of the criteria to be followed in the application of Article 50 of the Treaty of Montevideo. Some of the criteria used by the PTR based on the ECJ case law, such as the principle of proportionality and the necessity of the measure, were considered by the ad hoc tribunals. Nonetheless, a methodological approach on how to apply these criteria was missing from the ad hoc arbitral tribunal awards. In essence, the PTR gave a systematic order for how to deal with the exceptions to the free movement of goods. However, the PTR opted to overlook the understanding of the criteria developed by the ad hoc arbitral tribunals which have also been inspired, in some instances, by the ECJ case law jurisprudence. It would have been fruitful to see the review, or at least, the reference to these approaches by the PTR to reinforce the idea that there is a common understanding among the MERCOSUR dispute settlement organs that exceptions to the free movement of goods should be narrowly interpreted and subject to conditions such as proportionality and necessity of the unilateral measures.

The PTR needs to consider that the scope and breadth of Article 34 TFEU is not settled. Weatherill notes that "there are persisting questions about, first, the type of practice that is subject to control in the name of protecting the free movement of goods...". ${ }^{82}$ Over the years, there has been academic discussion about the limits of this provision in European integration ${ }^{83}$ and the new challenges that the ECJ case law faces in the current economic crises. ${ }^{84}$ The ECJ itself reviewed its broad interpretation of Article 34 TFEU given in its Dassonville ruling. Indeed, the ECJ set some limits to this formula in the well-known Keck and Mithouard judgment, where the ECJ decided that non-discriminatory selling arrangements are not measures of equivalent effect to quantitative restrictions (MEQRs) and therefore they are outside the scope of Article 34 TFEU. In MERCOSUR there is a need to develop a creative jurisprudence regarding the principle of free movement of goods.

\footnotetext{
${ }^{81}$ Complementary award issued on 13 January 2006 in Asuncion, Paraguay. Prohibition by Argentina on the Import of Remolded Tires from Uruguay, para. XVI.

${ }^{82}$ Weatherill, Stephen. Free movement of goods. ICLQ vol 61, April 2012 p. 541.

${ }^{83}$ White, Eric L. In search of the limits to Article 30 of the EEC Treaty. (1989) C.M.L. Rev. 235-280.

${ }^{84}$ Hojnik, Janja. Free movement of goods in a labyrinth: Can Buy Irish survive the crises? (2012) 49 Common Market Law Review, Issue 1, pp. 291-326.
} 
Such interpretation requires work to clarify and develop the concepts included in the treaties and to fill the gaps in the light of the integration process itself. This interpretation differs from a mere application of the ECJ jurisprudence. The question arises as to the limits of such application.

\subsection{Limitations to the freedom of states to impose restrictions on trade: the MERCOSUR law approach}

MERCOSUR law offers some guidance that could be useful for the interpretation of the principle of free movement of goods. So far, the criterion followed by the MERCOSUR law has been that the exceptions to the commitment to the elimination of non-tariff restrictions must be duly justified. Moreover, Article 7 of the 1994 Additional Protocol ACE No. 18, for example, required the State Parties to eliminate by no later than 31 December 1994 the non-tariff restrictions listed in the Annex of the Protocol. Exceptions to this obligation have to be duly justified. In the same vein, Article 1 of the said Protocol expressed the view that in the process of harmonization of non-tariff restrictions, non-tariff restrictions of a non-economic nature could be maintained for reasons duly justified by some of the State Parties. The Protocol reflects the approach taken up in Article 3 of the MERCOSUR Common Market Group Resolution No. 123/94. Therefore, only justifiable restrictions on trade could be accepted in MERCOSUR.

MERCOSUR organs have also shown interest in the correct utilization of the exceptions to the free movement of goods provided for in Article 50 of the Treaty of Montevideo. In this regard, in 2000, the Common Market Council adopted its Decision No. 57/00. This norm began in its Preamble highlighting the essential role played by this principle for the conformation of the common market. It remarked on the need to ensure fundamental principles such as the protection of life, health and public security but, more importantly, it stressed that the measures adopted for such purposes shall not create unnecessary obstacles to trade.

This Decision No. 57/00 sought specific commitments from the State Parties on the application of the exceptions to the free movement of goods. Consistent with this approach, Article 4 Decision No. 57/00 calls upon the Common Market Group to instruct the MERCOSUR Commission on Trade to initiate negotiations aimed at the regulation of the application of the measures adopted under the scope of Article 50 Treaty of Montevideo. According to this provision, this work should have been concluded before 31 May 2001 to be approved by the Common Market Council. This Decision shows that the highest MERCOSUR decision-making body implicitly recognized that there was a gap in Article 50 of the Treaty of Montevideo and sought to clarify and delimit its scope of application. Implicit in this Decision is the idea that such application should be assessed in the light of certain criteria or conditions, otherwise, why did the Common Market Council intend to regulate the measures adopted under the scope of Article 50 of the Treaty of Montevideo?

This approach is further confirmed when in 2010 the Common Market Group adopted Decision No. 56/2010, which established a Program to Consolidate the 
Custom Union in MERCOSUR. Several elements were included as part of this Program. One of these items was the free trade in MERCOSUR. In this context, Article 54 Decision No. 56/2010 deals with the measures to further free trade between MERCOSUR members. Interestingly, Article 54.3 thereof instructs the MERCOSUR Commission on Trade to set up a Working Group on Non-Tariff Measures. One of the objectives of this Working Group was to send to the Common Market Group, in the second semester of 2011, a proposal on the treatment of nontariff measures in light of Article 50 of the Treaty of Montevideo. In this respect, the Decision seeks to ensure that the utilization of exceptions to the free movement of goods does not constitute an obstacle to trade, understanding that the establishment of free trade among State Parties was part of the consolidation of the customs union. Consequently, it is difficult to accept that State Parties in MERCOSUR can use Article 50 Treaty of Montevideo without any conditions.

More importantly, this Decision was issued five years after the first PTR award of 2005 that attempted to set out the criteria for applying the exceptions provided for by Article 50 Treaty of Montevideo. Therefore, MERCOSUR institutions are seeking to provide a legal framework for the operation of the exceptions to free trade. The question of the conditions or criteria for such application remains open. It remains to be seen whether the legislative approach of MERCOSUR institutions will follow the PTR jurisprudence adopted in 2005 which, as we discussed above, heavily relied on the ECJ jurisprudence.

It is noteworthy that the Common Market Decision 09/95 also shed some light on the interest of the MERCOSUR organs in avoiding arbitrary restrictions on trade. This Decision approved the Program of Action of MERCOSUR until 2000. The Decision provides some rules about the elimination and harmonization of non-tariff restrictions and measures. In this area, the Decision stressed that the permanent objective is the elimination of non-tariff restrictions which constitute obstacles to trade. It remarks that this objective required permanent monitoring by the executive organs in order to avoid the introduction of new barriers. In the area of technical regulations, whereas it acknowledged their contribution to the protection of human health and the environment, it also required the elimination of unnecessary obstacles to trade. Notably, the Decision clarifies that such technical regulations should be applied in such a way as to avoid an arbitrary or unjustifiable discrimination or a disguised restriction on trade. These three conditions are enshrined in the preamble of Article XX of the GATT. In the same vein, the Common Market Decision 09/95 specifies some criteria concerning sanitary and phytosanitary regulations. It notes that the objective pursued is to ensure that such regulations do not constitute an unjustifiable obstacle to trade for products of animal or plant origin.

The 2000 Additional Protocol ACE No. 18 in MERCOSUR ${ }^{85}$ endorses these approaches taken up in secondary law. The Preamble of this Protocol expresses that free trade requires that technical regulations and standards, as well as procedures for

\footnotetext{
85 Acuerdo de Complementación Económica No 18 celebrado entre Argentina, Brasil, Paraguay y Uruguay (ACE No. 18). Additional Protocol signed on 29 December 2000.
} 
assessment of conformity adopted by State Parties, do not amount to unnecessary barriers to trade. Consequently, secondary law, along with the Protocols, reflects that restrictions on trade, even for the protection of health or the environment, are subject to certain conditions and should be necessary.

The PTR award in the Remolded Tires case did not reflect a court engaged in an interpretative exercise. The court could have done further research on MERCOSUR resources. It is submitted that the PTR erred in focusing exclusively on the ECJ case law as precedent to develop the criteria for applying the exceptions to the free movement of goods. The gap identified by the PTR should not be filled solely on the basis of the ECJ jurisprudence. First of all, the PTR should have attempted to identify how MERCOSUR law addressed trade barriers in general, and the exceptions to such trade barriers in particular. In MERCOSUR, inventories and classifications of non-tariff restrictions were made and lists of such restrictions were included in Protocols, Decisions and Resolutions. Thus, there are examples showing which national measures are to be regarded as restrictions on trade in MERCOSUR law. As we have seen, there is legislation that shows the clear intention of MERCOSUR organs to limit the utilization of trade barriers even when they are intended to protect public health or the environment. Only after such analysis, should the ECJ case have served, as the PTR put it, as an illustration on the matter.

The mere fact that there is a general rule of prohibition on restrictions along with a list of exceptions to this rule triggers a two-tier approach. Obviously, there cannot be an exception if a restriction on trade does not exist. First, the provisions concerning the free movement of goods call for the determination of the existence of a restriction. Second, a determination of whether such a restriction could be covered by one of the exceptions listed in the Treaty of Asuncion is required. A close reading of Article 1 and Article 2 b) Annex 1 of the Treaty of Asuncion and Article 50 of the Treaty of Montevideo reflects that such exceptions cannot be accepted unless they can be duly justified. This understanding is further supported by the subsequent Protocols and legislation adopted by the MERCOSUR organs. These provisions (save for the legislation issued in 2010) could have been taken into account by the PTR in its award of 2005 to emphasize the consensus among State Parties that in the context of Article 50 of the Treaty of Montevideo, restrictions on trade should be justified and needed. However, the PTR did not resort to MERCOSUR legislation in its interpretation. The PTR has limited itself to reproducing the ECJ jurisprudence to interpret the Treaty of Asuncion without further consideration being given to other sources. In an integration process, a critical analysis demands a review of other sources, such as the internal legislation to find the criteria, the objectives and principles commonly expressed by the treaties, and secondary law passed by MERCOSUR organs.

The PTR is convinced that the Treaty of Asuncion shall be interpreted in the same manner as the ECJ interpreted the provisions on the free movement of goods. Indeed, The PTR has assumed that the interpretation given by the ECJ to Articles 34 and 36 of the TFEU is applicable to the interpretation of the provisions of the Treaty of Asuncion. The reference made by the PTR to the Guide to the Concept and 
Practical Application of Articles 28-30 EC of $2001^{86}$ (now Articles 34-36 of the TFEU) clearly indicates the PTR's choice to apply the interpretation of the ECJ to clarify the scope of the principle of free movement of goods in MERCOSUR.

\subsection{The PTR interpretation and application of MERCOSUR law}

Some scholars in MERCOSUR have criticized the utilization of the European jurisprudence by the arbitral tribunals and deny the competence of the arbitral tribunals to declare the law. Drnas de Clément questioned the function of the arbitral tribunals and the PTR as regards the interpretation of MERCOSUR law. In her view, the award of the PTR of 2005 in the Remolded Tires case should be criticized for the following reasons: a) the PTR disregarded the explicit MERCOSUR legislation, b) the PTR resorted to the jurisprudence of the ECJ as a guide and source of law without noting the differences in the regulations between the two systems, the different nature of the processes and the limitations imposed by the Protocol of Olivos on the arbitrators. Drnas de Clément takes the view that the arbitral tribunals are guilty of an abuse of power or abuse of function because they have directly transplanted the European and Andean jurisprudence disregarding the fact that MERCOSUR is not a community system and that they are merely arbitral tribunals. $^{87}$ Drnas de Clément criticized the arbitral tribunals, arguing that the measures under Article 50 of the Treaty of Montevideo do not constitute exceptions to free trade in MERCOSUR because, in her view, Annex I Article 2 b) excludes from the concept of restrictions the measures adopted under Article 50 Treaty of Montevideo and therefore, she argues, they are not restrictions. She concludes that this provision incorporates a general power which does not require any other condition but rather that the measure should be aimed at the objective provided for and authorized in the Treaty. ${ }^{88}$

Although the manner in which the PTR used the ECJ jurisprudence deserves some criticism, we do not fully agree with the position expressed by Drnas de Clément.

First, as Vinuesa states, the PTR "was established with the main purpose of harmonizing the interpretation and application of Mercosur law." 89 The Protocol of Olivos explicitly mentions the law that arbitral tribunals and the PTR should apply to the controversies between State Parties. ${ }^{90}$ However, the Protocol does not prohibit the utilization of any jurisprudence in the decision of the arbitral tribunals or the PTR. The jurisprudence is not a source of law but rather a source of interpretation of

\footnotetext{
${ }^{86}$ Philipson, A. Guide to the Concept and Practical Application of Articles 28-30 EC. European Commission, Internal Market DG, 2001.

${ }^{87}$ Drnas de Clément, Zlata. La "cláusula ambiental” en el MERCOSUR. Paper presented at the XXI Congreso Argentino de Derecho Internacional "Dr. Enrique Ferrer Vieyra”, Córdoba, 1-3 October 2009. (10.07.2013). 7, 10-12 http://www.acaderc.org.ar/doctrina/articulos/la-clausula-ambiental-en-el-mercosur

${ }^{88}$ Drnas de Clément, Zlata. Op. cit. pp. 10-11,12 (10.07.2013).

${ }^{89}$ Vinuesa. Op.cit. p. 438.

${ }^{90}$ Article 34 of the Protocol of Olivos.
} 
the law. ${ }^{91}$ Tribunals may use jurisprudence as a guide or for illustration of a subject matter. A question arises when a tribunal completely relies on foreign jurisprudence without first making an exhaustive review of the internal instruments which could shed light on the interpretation of the law at hand.

Second, a comparison of the TFUE and the Treaty of Asuncion reveals that the two treaties show some similarities as well as differences regarding how they regulate the principle of free movement of goods. The clearest similarity, and this is relevant in this analysis, is that both treaties prohibit the application of non-tariff restrictions on trade and measures of equivalent effect. Unlike the TFUE, the Treaty of Asuncion does define the concept of restrictions. Nevertheless, although the same term of measures of equivalent effect has been used in both treaties, it does not necessarily imply that the same interpretation applies. In this context, it is noteworthy that not all agreements that have introduced the concept of MEQR have employed the ECJ case law concerning the free movement of goods. For example, Switzerland concluded a free trade agreement (FTA) with the EC (now the EU) in 1972. Article 13 thereof provides that "No new quantitative restriction on imports or measures having equivalent effect shall be introduced in trade between the Community and Switzerland." Some commentators have questioned whether it is legitimate to consider that Dassonville can be transposed to this provision and have pointed out that Swiss doctrine has shown, in this respect, extreme care by noting the difference in objectives between the FTA and the now TFEU. ${ }^{92}$ On the other hand, it has been noted that "the Swiss Federal Tribunal has not accepted the Cassis de Dijon principle as relevant for its interpretation of either Art. 13 FTA (imports) nor of Art. 13A FTA (exports)." ${ }^{93}$ Thus, the application of Dassonville may depend on the expected or established level of integration.

Third, Article $2 \mathrm{~b}$ ) Annex I of the Treaty of Montevideo which shall be read together with Article 50 Treaty of Montevideo provides for the exceptions to the free movement of goods. It is true that Article 2 b) Annex I of the Treaty of Montevideo excludes the measures adopted under the framework of Article 50 Treaty of Montevideo from the concept of restrictions. The same wording is used in the Cartagena Agreement (by the Andean Community). This legislative technique concerning the manner in which exceptions to the free movement of goods have been regulated may lead to confusion and error. Measures may be adopted to protect the public interest objectives permitted by Article 50 Treaty of Montevideo; however, the restrictive nature of such measures does not change. Indeed, by excluding measures adopted for protecting non-trade policies from the concept of

\footnotetext{
${ }^{91}$ Mejía Herrera, Orlando. El diálogo entre tribunales: la jurisprudencia del Tribunal de Justicia de la Unión Europea como fuente de inspiración para los tribunales de los sistemas de integración latinoamericanos. Boletín Electrónico sobre Integración Regional del CIPEI No. 1. May 2011, p. 21.

92 Jacot-Guillarmod, Olivier. Le juge national face au droit europeen: Perspective suisse et communautaire (Dossier de droit europeen, No.3) Brussels: Bruylant 1993, p. 230.

93 Tobler, Christa, Hardenbol, Jeroen and Mellár, Balázs. Internal Market beyond the EU: EEA and Switzerland. Briefing Paper. Directorate General for Internal Policies, European Parliament, 2010, p. 23.

http://www.europarl.europa.eu/document/activities/cont/201003/20100315ATT70636/20100315ATT 70636EN.pdf.
} 
restrictions, the Treaty suggests that they should not be regarded as restrictions on trade and overlooks the fact that the restrictions on trade continue to exist even though they are justified. Reliance on the exceptions presupposes the existence of a restriction on trade.

Notably, the same mistake is found in the case law of the ECJ. Gormley, quoting the ECJ judgment in Commission v. Italy (Case C-110/05 of 2009), found the same line of assessment used by the ECJ. He correctly adds "If a measure is justified, it does not cease to be a measure having equivalent effect; it is merely a measure which is accepted, having been reviewed for necessity and proportionality, because of the interest or value pursued. The trade-restricting effects do not disappear! This logical mistake is all too frequently made and really ought to stop." 94 Therefore, the arbitral tribunals and the PTR did not make a mistake in regarding Article 50 Treaty of Montevideo as an exceptional rule. However, the PTR may have made the same mistake when it quoted the ECJ case law as regards the manner in which a restriction is contrary to the treaty unless it can be justified.

Fourth, the fact that Article $2 \mathrm{~b}$ ) Annex I Treaty of Montevideo and Article 50 Treaty of Montevideo did not include qualifications for the application of the measures listed by the latter does not mean that such measures are not subject to certain conditions. The understanding of the MERCOSUR law has been that unnecessary obstacles to trade cannot be accepted. The MERCOSUR organs have also shown concern for the correct utilization of such measures, as we have discussed above. The arbitral tribunals' attempt to clarify some conditions pertinent to the application of such measures cannot be seen as a deviation of power. Instead, they show a clear understanding of the objectives of the Treaty of Asuncion. The PTR should have relied more on the legislation of MERCOSUR, with a teleological interpretation, than on the European jurisprudence to emphasise the need for such conditions. In any integration system, regardless of its supranational or intergovernmental nature, it cannot be admissible that states invoke exceptions to the free movement of goods in an arbitrary manner. Unilateral and arbitrary obstacles to trade are what this principle seeks to avoid. The MERCOSUR legislation recognizes the importance of a market free of obstacles.

Fifth, the PTR award does not express its intent to promote integration in MERCOSUR with the application of the European jurisprudence, which is an objective that has been explicitly stated by the Andean Community institutions when using the ECJ case law. ${ }^{95}$ In this regard, the PTR showed a more pragmatic approach. It identified that there was a legal gap and resolution of the case required this gap to be filled. In order to provide a solution, it applied the ECJ case law without further justification of its choice. In its complementary award, the PTR defended its institutional role.

\footnotetext{
${ }^{94}$ Gormley, Laurence W. Free Movement of Goods and Their Use -What Is the Use of It? In: Fordham International Law Journal Vol. 33, Issue 6, 2011,p. 1614.

${ }^{95}$ Reyes Tagle, Yovana, op. cit.p.24.
} 
The prestige of the ECJ and the recognition of its intellectual work as an interpreter of community law in Europe has led to the idea that such work is worthy of being employed in Latin America. Some scholars commented on the PTR award and criticized the position of Argentina when it intended to disregard the value of the ECJ jurisprudence in the Remolded Tires case. Mejía Herrera argues that Argentina was not right when it sought to disregard the legal value of a serious and respectable jurisprudence such as that of the ECJ. In his view, the European jurisprudence can be regarded as a source of interpretation, inspiration and orientation to other supranational tribunals in an integration process so long as such jurisprudence is reasonably and objectively used and pertinent to the case at hand. ${ }^{96}$

When is there a reasonable and objective utilization of the ECJ jurisprudence in a decision of an arbitral tribunal in MERCOSUR? One needs to consider that the jurisprudence of the ECJ was developed to interpret the European norms in the light of the European integration process. The ECJ has repeatedly resorted to a teleological interpretation of community law taking into account the ends and objectives of the European integration. The principle of free movement of goods with the adoption of the ECJ's Dassonville formula responds to such a conception. ${ }^{97}$ The ECJ definition of measures of equivalent effect reflects certain political and economic choices. The development of the ECJ case law regarding Article 34 TFEU is the consequence of the development of the European state of integration. ${ }^{98}$ This formula, as Chalmers puts it, "reflects a philosophy of extreme economic liberalism". 99 Thus a reasonable and objective utilization of the ECJ jurisprudence should require a creative jurisprudence developed in the light of the integration process at hand. The PTR sees itself as concerned with establishing a jurisprudence that would serve future tribunals to assess the exceptions to the free movement of goods. However, merely copying the concepts and principles enshrined by the ECJ as the only source to interpret the law in an integration process is difficult to accept from a tribunal, let alone when a tribunal seeks to set up leading jurisprudence.

\section{Interpretation of the exceptions to the free movement of goods: the Treaty of Asuncion and other Latin America treaties}

Is there really a gap when an agreement does not include further qualifications or conditions for the exceptions to the free movement of goods? Is it not implicit in the provisions of the Treaty of Asuncion, like any other agreement, that arbitrary and unnecessary restrictions on trade cannot be allowed? The wording of the definition

\footnotetext{
${ }^{96}$ Mejía Herrera, op.cit. p.22.

http://www.boletincipei.unanleon.edu.ni/documentos/articulos/art1.pdf (12.07.2013)

${ }^{97}$ The ECJ has ruled that "all trading rules enacted by Member States which are capable of hindering, directly or indirectly, actually or potentially, intra-community trade are to be considered as measures having an effect equivalent to quantitative restrictions." Case 8/74 Procureur du Roi v Benoît and Gustave Dassonville [1974] E.C.R 00837.

${ }^{98}$ Wils, Wouter P.J. The search for the rule in Article 30 EEC: much ado about nothing? (1993) E.L.Rev., p. 485.

${ }^{99}$ Chalmers, Damian. Free movement of goods within the European Community: an unhealthy addiction to Scotch whisky? (1993) 42 E.L.Rev., p. 275.
} 
of restrictions contained in Article 2 b) of Annex I of the Treaty of Asuncion is, with minor changes in some instances, similar to the definition of this concept incorporated in the commercial agreements signed between the Latin American countries which are members of the Latin American Integration Association (ALADI). As an example, in the 1980s and 1990s, Argentina, Brazil, Bolivia, Colombia, Chile, Ecuador, Mexico, Paraguay, Peru, Uruguay, and Venezuela signed between them Partial Scope Agreements under the framework of the ALADI system.

A review of some of these agreements reveals that they contain the same definition of restrictions as provided in the Treaty of Asuncion, and as such, they have not introduced any conditions or regulated the manner in which the exceptions to the removal of non-tariff restrictions will be made. In this sense, these Latin American agreements have included exceptions to such removal to those spelled out in Article 50 of the Treaty of Montevideo. ${ }^{100}$ Consequently, this has been one common technique used by the drafters of these treaties in Latin America when dealing with exceptions to the imposition of non-tariff restrictions. The original Cartagena Agreement that created the Andean Pact (now the Andean Community) in 1969 used the same formula.

In any case, states are aware that all the unilateral restrictive measures adopted as exceptions to the obligation of elimination of non-tariff restrictions are always subject to review under the proper means of the dispute settlement system provided for in their agreements. In this context, the assessment of why and how restrictions on trade are used will be conducted. This fact proves that there are some limitations to the state power to impose restrictions on trade even when a public policy objective is being protected. The fact that the agreements of these Latin American countries have not included any conditions for invoking the exceptions laid down in Article 50 of the Treaty of Montevideo does not mean that states can employ these exceptions without limits. It is submitted that these countries understood that arbitrary restrictions which are not aimed at protecting the interests spelled out in the treaties cannot be accepted. Then, it is the task of the dispute settlement organs provided for in the agreements to interpret on a case-by-case basis whether a restriction on trade is arbitrary.

\footnotetext{
${ }^{100}$ Article 3 of the Partial Scope Agreement $N^{\circ} 1$ signed on 20 December 1982 between Argentina and Uruguay, Articles 2 and 7 of the Partial Scope Agreement $N^{\circ} 23$ signed on 2 April 1993 between Chile and Venezuela, Article 7 of the Partial Scope Agreement N ${ }^{\circ} 16$ signed on 2 August 1991 between Argentina and Chile, Article 9 of the Partial Scope Agreement of Renegotiation (Protocol) $\mathrm{N}^{\mathrm{o}} 29$ signed on 31 May 1993 between Ecuador and Mexico, Article 3 of the Partial Scope Agreement of Renegotiation (Protocol) No 38 signed on 31 May 1993 between Mexico and Paraguay, Article 4 of the Partial Scope Agreement No 22 signed on 6 April 1993 between Bolivia and Chile, Article 3 of the Partial Scope Agreement $N^{\circ} 25$ signed on 31 December 1993 between Brazil and Peru, Article 4 of the Partial Scope Agreement No 9 signed on 11 March 1988 between Argentina and Peru, Article 3 of the Partial Scope Agreement No 11 signed on 28 April 1988 between Argentina and Colombia. These agreements are available at: http://www.aladi.org/nsfaladi/arquitec.nsf/VSITIOWEB/Sumarios_Textos_y_Disposiciones_Historic os.
} 
Another aspect that is noteworthy is that, in the late 1990s, Brazil, Colombia, Ecuador, Peru and Venezuela signed the Partial Scope Agreement $\mathrm{N}^{\circ} 39 .{ }^{101}$ According to Article 6 thereof Member States can neither maintain nor introduce new non-tariff restrictions for the products negotiated in the Agreement. Article 7 of said Agreement stipulates the possibility to apply exceptions to the obligations of the Agreement, among them, the obligation to eliminate restrictions. Taking a completely new approach, this provision not only refers to the exceptions spelled out by Article 50 of the Treaty of Montevideo but also introduces Articles XX and XXI of the General Agreement on Tariffs and Trade (GATT) as possible justifications. Thus, the three tests of the leading paragraph of Article XX are incorporated in the analysis concerning how the exceptions are applied by the Member States.

\section{Conclusion}

The analysis of the case law of the PTR reveals that the ECJ jurisprudence gives to the MERCOSUR law its orientation. The PTR looks to the ECJ case law to give meaning to the MERCOSUR law. Although the ECJ jurisprudence could shed some light on the interpretation of certain rules, such case law has been used as de facto authority. Such a conclusion holds true in particular for the interpretation of MERCOSUR law where a legal vacuum is identified. The manner in which the PTR quotes the ECJ case law and immediately after, without further consideration of other sources, completely applies such case law supports this view. A more creative interpretation of MERCOSUR law is called for. The construction of a case law developed in the light of the MERCOSUR integration process itself is required. Taken together, the PTR reasoning in the three rulings on the occasion of the Remolded Tires case demonstrates the willingness of the PTR to follow the ECJ jurisprudence. The PTR could have engaged in a thorough review of MERCOSUR legislation which could have shed light on the scope of the exceptions to the free movement of goods.

\footnotetext{
${ }^{101}$ Partial Scope Agreement No 39 signed on 12 August 1999 between Colombia, Ecuador, Peru and Venezuela Members Countries of the Andean Community and Brazil. Venezuela is no longer a Member of the Andean Community.
} 